\title{
Environmental Factors Affecting the Release and Dispersal of Ascospores of Mycosphaerella citri
}

\author{
S. N. Mondal, T. R. Gottwald, and L. W. Timmer
}

First and third authors: University of Florida, Citrus Research and Education Center, and Department of Plant Pathology, 700 Experiment Station Road, Lake Alfred 33850; and second author: U.S. Department of Agriculture, Agricultural Research Service, Horticultural Research Laboratory, Ft. Pierce, FL 34945.

Accepted for publication 21 March 2003.

\begin{abstract}
Mondal, S. N., Gottwald, T. R., and Timmer, L. W. 2003. Environmental factors affecting the release and dispersal of ascospores of Mycosphaerella citri. Phytopathology 93:1031-1036.

Greasy spot, caused by Mycosphaerella citri, produces a leaf spot disease affecting all citrus species in Florida and the Caribbean Basin. $M$. citri produces pseudothecia and ascospores, which are considered the principal source of inoculum, in decomposing leaves on the grove floor. In studies using a computer-controlled environmental chamber, a single rain event triggered release of most mature ascospores beginning 30 to $60 \mathrm{~min}$ after the rain event. Additional rain events did not bring about further release. High relative humidity without rain triggered release of low numbers of ascospores, but vibration and red/infrared irradiation had little or no effect on ascospore release. After three to four cycles of

wetting and drying of leaves, all pseudothecia had matured and released their ascospores. In the field, ascospores were detectable starting about $2 \mathrm{~h}$ after the beginning of a rain or irrigation and most ascospores were released within $16 \mathrm{~h}$. Ascospore release was greatest following rain events and somewhat less following irrigations, and low numbers of ascospores were detectable on days without precipitation. Ascospore numbers declined linearly with horizontal distance from the source and as a function of the logarithm of ascospore numbers with vertical distance. Low numbers of ascospores were detected $7.5 \mathrm{~m}$ above the ground and $90 \mathrm{~m}$ downwind from the grove. Ascospore release can be advanced by irrigating frequently during dry, nonconducive conditions to stimulate ascospore release when environmental conditions are unfavorable for infection, but the eventual effects on disease severity are uncertain.
\end{abstract}

Greasy spot, caused by Mycosphaerella citri Whiteside, is a leaf spot disease that produces premature leaf drop accompanied by reduced tree vigor, yield, and fruit size (22). M. citri also infects fruit causing greasy spot rind blotch, which reduces the acceptability of fruit for the fresh market. The disease is most severe on grapefruit and its hybrids, but affects all citrus. It is prevalent in Florida and most of the Caribbean Basin, and other greasy spot-like diseases occur elsewhere $(8,23)$.

$M$. citri is a loculoascomycete fungus, and ascospores are produced in pseudothecia in decomposing leaf litter on the grove floor. Most of the leaf drop in Florida citrus groves occurs in January and February. Whiteside (26) demonstrated that alternating wetting and drying was needed for pseudothecial development in dead, infected leaves. Mondal and Timmer (18) found that wetting infected leaves three times a week for 30 to $60 \mathrm{~min}$ resulted in maximal production of pseudothecia. The optimum temperature for pseudothecial production was $28^{\circ} \mathrm{C}$. Once pseudothecia and ascospores are mature, wetting the leaves triggers the release of ascospores. Most of the ascospores are released in a few hours after the leaves are wetted (7). In Florida, peak ascospore release under grove conditions previously occurred in June and July at the beginning of the rainy season (26). Spore release now peaks in April-May $(21,25)$ because microsprinkler irrigation moistens leaf litter two to three times per week and accelerates leaf decomposition (25). Peak release in Costa Rica occurs in June shortly after the rainy season begins (8). In Texas, where rains begin later, peak release occurs in July-August (24). Ascospores are deposited on the leaf surface where they germinate and mycelium grows epi-

Corresponding author: S. N. Mondal; E-mail address: smondal@lal.ufl.edu

Publication no. P-2003-0617-01R

(C) 2003 The American Phytopathological Society phytically. In Florida, the epiphytic growth begins to develop in late June or early July and continues through September (17). Hyphal tips penetrate the leaves through stomata. $M$. citri grows slowly in the mesophyll and symptoms of chlorosis and necrosis develop after several months, usually in November-December, in Florida.

The effects of environmental factors on the release and dispersal of ascospores of Venturia inaequalis, V. pirina, Apiosporina morbosa, and Anisograma anomala that cause apple scab, pear scab, black knot of cherry, and eastern filbert blight, respectively, have been extensively studied $(3,6,10,12,14,20)$. Other than the fact that ascospore release follows the wetting of decaying leaves with mature pseudothecia of $M$. citri $(23,26)$, little is known about the factors that trigger release, the duration of ascospore production from leaves, and dispersal of ascospores.

The purpose of this study was to determine the effect of rainfall events, relative humidity $(\mathrm{RH})$, red/infrared (R/IR) radiation, and vibration on the release of ascospores of $M$. citri under laboratory conditions. Under field conditions, the effect of rain events and irrigations on ascospore release, as well as the vertical and horizontal dispersal of ascospores was investigated.

\section{MATERIALS AND METHODS}

Computer-controlled environmental chamber studies. General. Mature leaves with symptoms of greasy spot were collected from grapefruit (Citrus paradisi Macf.) trees that had not been treated with fungicide. Leaves were air dried in the laboratory at ambient temperature 23 to $27^{\circ} \mathrm{C}$ and stored in paper bags until used. Dried leaves were wetted for 10 to 30 min per day, 5 days per week at $28^{\circ} \mathrm{C}$, and dried between wettings to induce formation of pseudothecia (18). After pseudothecial development, about 10 to 15 pseudothecia were dissected periodically from the leaf tissue, squash-mounted in lactophenol-acid cotton blue (5), and examined microscopically to determine pseudothecial maturity. Pseudo- 
thecia matured in about 40 days. Leaves selected for ascospore release studies had pseudothecia distributed over more than half of the leaf surface and more than $50 \%$ of the pseudothecia matured with no or few pseudothecia that had already ejected ascospores.

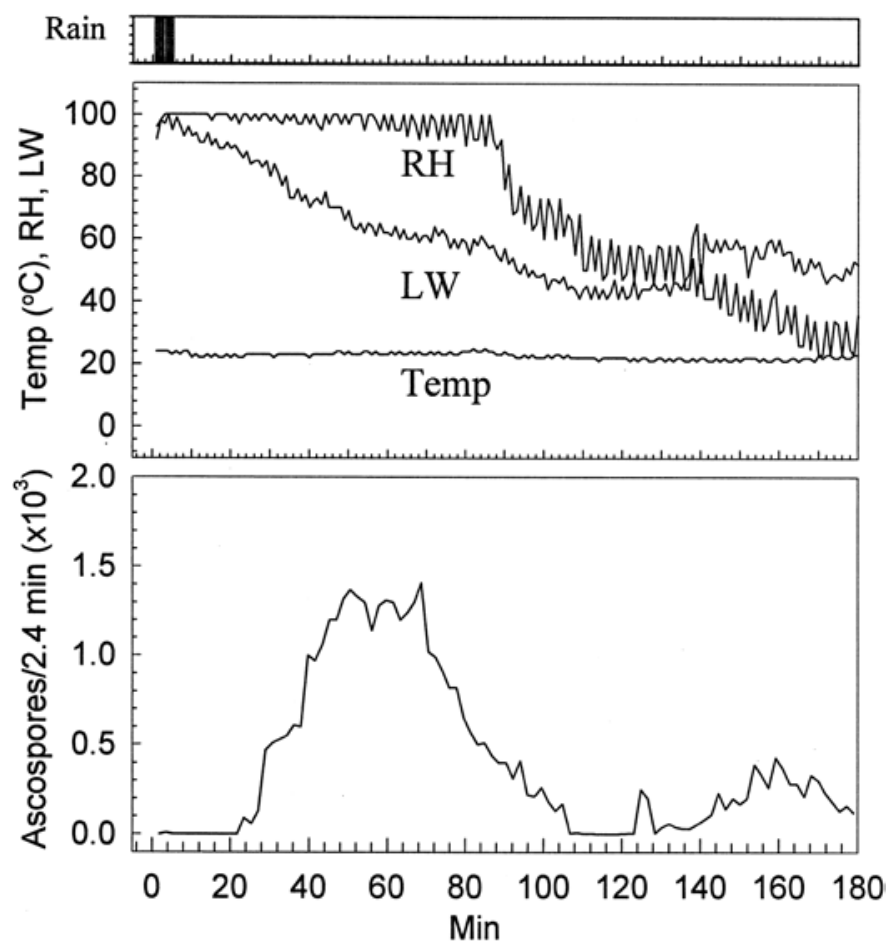

Fig. 1. Release of ascospores from pseudothecia of Mycosphaerella citri in response to a single rain event in a computer-controlled environmental chamber, under the relative humidity (RH), leaf wetness (LW), and temperature (Temp) described.

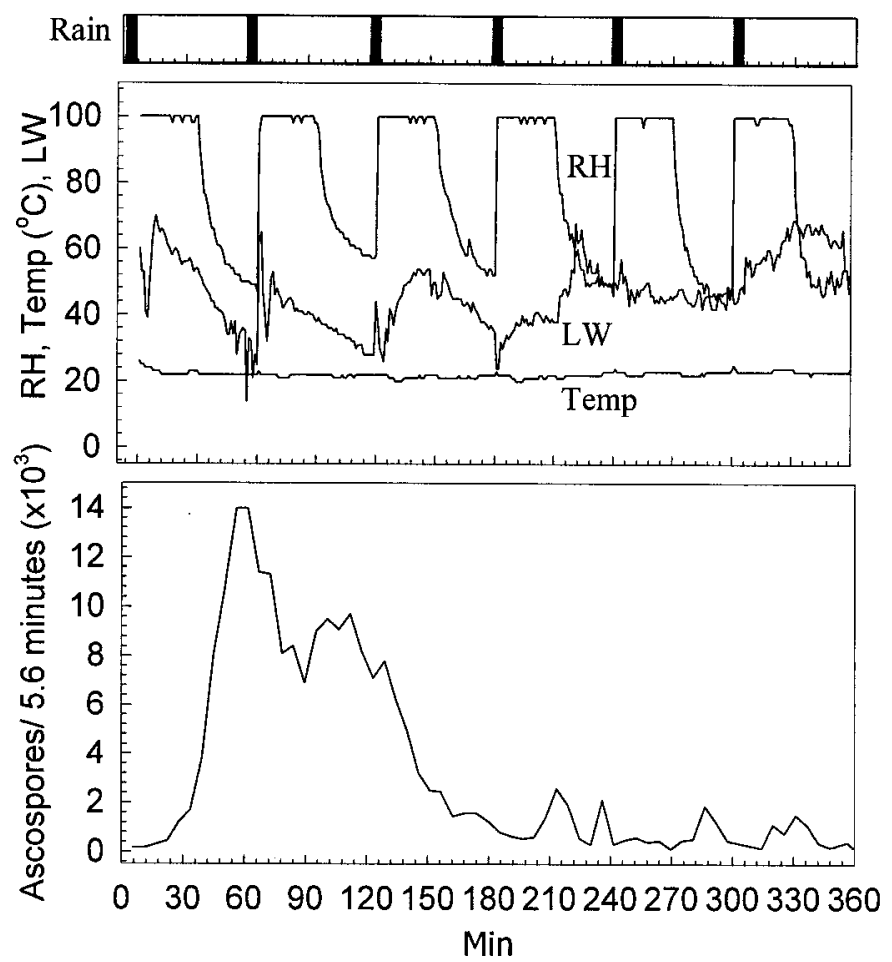

Fig. 2. Release of ascospores from pseudothecia of Mycosphaerella citri in response to multiple rain events in a computer-controlled environmental chamber, under the relative humidity (RH), leaf wetness (LW), and temperature (Temp) described.
A computer-controlled environmental chamber (CCEC), designed and described by Gottwald et al. (7), was used to investigate the effects of environmental factors affecting release of ascospores. The device was used to control, manipulate, and monitor rainfall, temperature, RH, R/IR radiation, leaf wetness, vibration, and air flow (wind speed). For each experiment, four leaves were placed in the sample holder and subjected to the treatments of the above variables as described for each experiment. Spores released from the samples were trapped on a rotating spore trap to allow correspondence of spore release with environment variables and their changes. The spore trap was calibrated to rotate at a constant rate, functioning on the same principle as a Burkard volumetric spore trap (Burkard Scientific Sales, Ltd., Rickmansworth, Hertfordshire, UK), and used the same trapping surfaces prepared in the manner as described below.

Effect of rain. Three experiments were conducted to determine the effect of a single rain event on ascospore release. Because the chamber can flood with excess rain, prolonged simulated rains were not tested. A single rain event was composed of five rains of $5 \mathrm{~s}$ each at 1-min intervals. Leaves were exposed to a single rain event at time 0 , and ascospores were collected for $180 \mathrm{~min}$. The temperature was maintained at 23 to $24^{\circ} \mathrm{C}$, and $\mathrm{RH}$ was held at 95 to $100 \%$ for the first $80 \mathrm{~min}$ and then reduced to 20 to $40 \%$ for the duration of the experiment. The number of ascospores trapped during each 30-min period was averaged for the three experiments, transformed to $\log _{10}$, and the data were regressed against time. The first 30-min period was omitted from the regression analysis because no ascospores were released.

Three experiments were conducted to determine the effect of multiple rains on ascospore release. Leaf samples were exposed to six rain events, as defined previously, at about 1-h intervals, and ascospores were collected for $360 \mathrm{~min}$. The $\mathrm{RH}$ was held at 95 to $100 \%$ for the first 30 min following each rain event and then reduced to $50 \%$ until the next rain event. Temperature was maintained at 23 to $25^{\circ} \mathrm{C}$. The number of ascospores collected for 180 min during and after each rain event was averaged across the

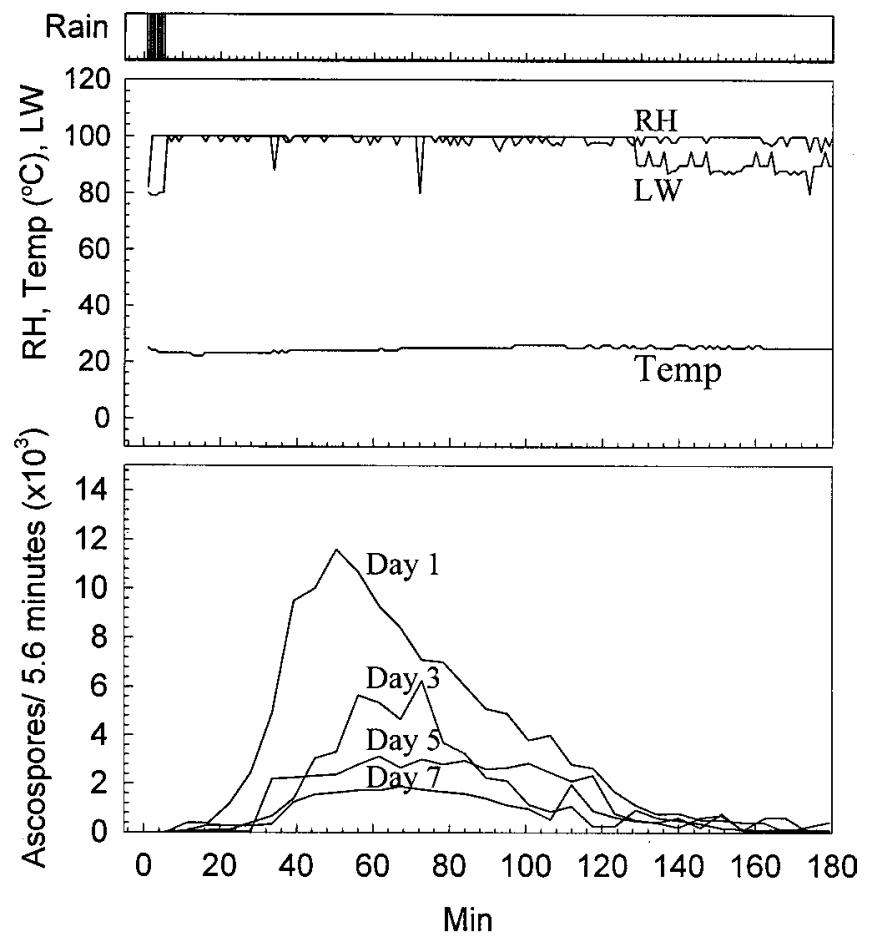

Fig. 3. Effect of successive wetting and drying of leaves on the release of ascospores from pseudothecia of Mycosphaerella citri in a computercontrolled environmental chamber. Leaves were dried under laboratory conditions between exposure periods, under the relative humidity $(\mathrm{RH})$, leaf wetness (LW), and temperature (Temp) described. 
three experiments. The average number of ascospores was transformed to $\log _{10}$ and was regressed against the number of the rain event, i.e., 1 to 6 .

Successive wetting and drying. Three experiments were conducted to determine the effect of repeated wetting and drying on ascospore release. In each experiment, a leaf sample was placed in the chamber, exposed to a single rain event, and then ascospores were captured for $180 \mathrm{~min}$ on day 1 . The RH was maintained at 95 to $100 \%$ following the rain events and the temperature was 23 to $24^{\circ} \mathrm{C}$. Then, the sample was dried under laboratory conditions at 23 to $27^{\circ} \mathrm{C}$ and about 40 to $70 \% \mathrm{RH}$, and the process was repeated on days 3,5 , and 7. The number of ascospores trapped each time was averaged for the three experiments, transformed to the $\log _{10}$, and regressed against the day of exposure to rain.

$R H$. Two experiments were conducted to determine the effect of constant high $\mathrm{RH}$ on ascospore release. Leaf samples were exposed at 95 to $100 \% \mathrm{RH}$ at 25 to $27^{\circ} \mathrm{C}$ and the ascospores released were collected for $360 \mathrm{~min}$. Means were calculated for each 30-min period, averaged across the two experiments, transformed to $\log _{10}$, and regressed against time for the constant $\mathrm{RH}$ experiments.

$R / I R$ irradiation and vibration. The effect of a single $\mathrm{R} / \mathrm{IR}$ exposure in the absence of vibration was evaluated in two experiments. The leaf sample was exposed to a single rain at time 0 . The sample was exposed to R/IR during the first $15 \mathrm{~min}$ of the experiments. The RH was maintained at 80 to $100 \%$ and the temperature at 22 to $23^{\circ} \mathrm{C}$. The effects of R/IR irradiation and of vibration to simulate wind movement of leaves were determined in two additional experiments. After a rain event at time 0 , samples were exposed to two periods of R/IR irradiation at 60 and $120 \mathrm{~min}$, each $15 \mathrm{~min}$ in duration. Momentary vibrations were imposed at 30, 60, 90, and $120 \mathrm{~min}$. The length of the experiments was 180 min, during which time the RH was maintained at 95 to $100 \%$ and the temperature at about $24^{\circ} \mathrm{C}$.

Field studies. Rain and irrigation effects. The effect of rain events and microsprinkler irrigations on the release of ascospores was determined with a Burkard volumetric spore sampler (Burkard Scientific Sales). The sampler was placed in a grove of mixed citrus at the Citrus Research and Education Center in Lake

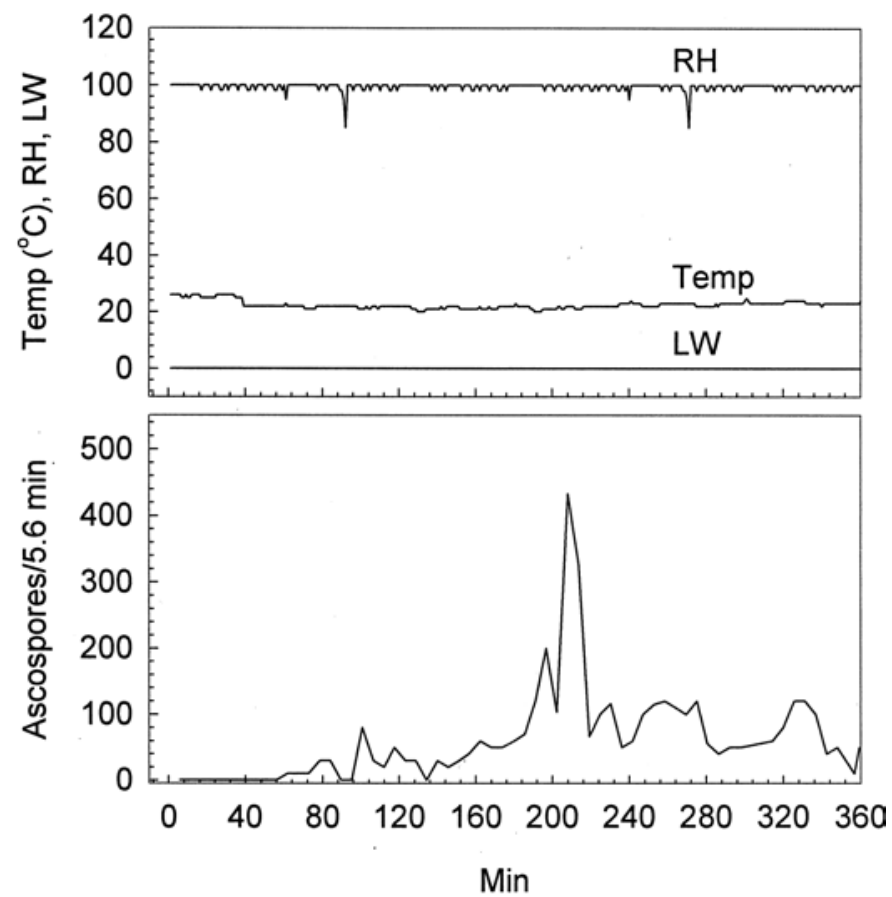

Fig. 4. Release of ascospores from pseudothecia of Mycosphaerella citri in response to continuous high relative humidity without rain in a computercontrolled environmental chamber, under the relative humidity (RH), leaf wetness (LW), and temperature (Temp) described.
Alfred, FL. Coatings for the spore trap tape, handling of tapes, and counting of ascospores were as described previously (25). The spore sampler was operated for $24 \mathrm{~h}$ following rain events on 17 to 18 May, 27 to 28 May, and 7 to 8 June 2002 to determine the release pattern of ascospores in response to wetting under field conditions. The spore sampler was operated continuously from 1 May to 15 June 2000, 15 April to 15 June 2001, and 15 April to 10 June 2002, during the peak ascospore release period to determine the effect of irrigations and rain events. Rainfall data were collected from an automated weather station located within $500 \mathrm{~m}$ of the grove. Dates of irrigations and the amount of water applied were recorded during the above periods. Analysis of variance was used to compare the $\log _{10}$ of the number of ascospores released on days with rain events or irrigations with those with no precipitation.

Dispersal. Experiments were conducted in 2002 to determine the horizontal and vertical distribution of ascospores adjacent to a mixed planting of citrus species of about 5 ha from Lake Alfred. Four Burkard spore samplers were operated continuously from 29 April to 10 June 2002 at $0.5,30,60$, and $90 \mathrm{~m}$ downwind from the grove edge. Total ascospores captured each week were squareroot transformed and regressed against distance. Four weekly samplings were conducted.

Vertical dispersal was determined by mounting AGI-30 liquid impinger air samplers (Ace Glass, Inc., Vineland, NJ) on rotating platforms so the orifice was always oriented into the wind (20). The samplers were connected to a manifold and then to a vacuum pump using 10-mm-diameter tygon tubing. Each sampler drew air at 10 liters per minute. One spore sampler was located at 0.5, 2.5, 5.0 , and $7.5 \mathrm{~m}$ above the ground on a tower $5 \mathrm{~m}$ from the edge of the grove. Sampling was conducted during and following rain events on 27 May, 29 May, and 31 June 2002. A 50\% glycerol solution $(10 \mathrm{ml})$ was placed in each sampler, the vacuum pump was operated for about $5 \mathrm{~h}$, and the liquid was collected. The number of ascospores per 10-ml sample was determined by a hemacytometer. Nonlinear regression analysis was used to relate ascospore number and height above the ground.

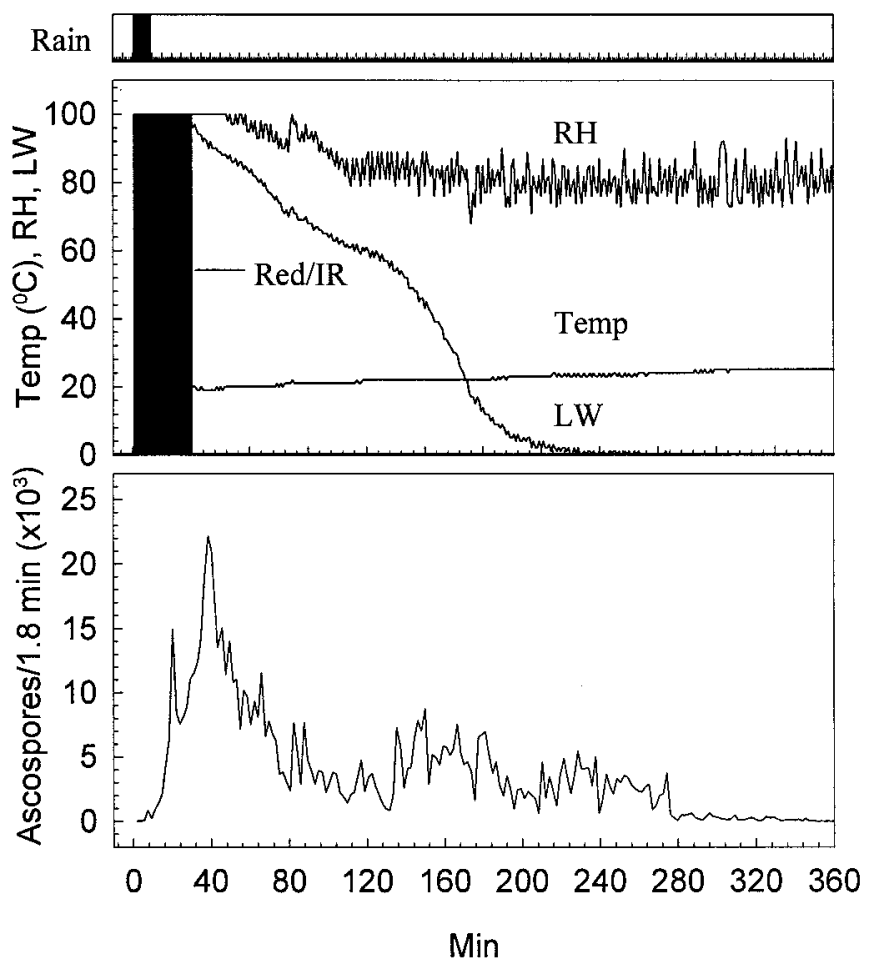

Fig. 5. Release of ascospores from pseudothecia of Mycosphaerella citri in response to a single rain event and exposure to red/infrared irradiation in a computer-controlled environmental chamber, under the relative humidity (RH), leaf wetness (LW), and temperature (Temp) described. 


\section{RESULTS}

Computer-controlled environment chamber studies. Effect of rain. A single rain event usually triggered release of large numbers of ascospores about 30 min later as shown in a typical experiment (Fig. 1). Peaks usually occurred within the first $60 \mathrm{~min}$, after which release declined with occasional small peaks. Across all three experiments, $57 \%$ of the ascospores were captured in the first hour following a rainfall event. The number of spores trapped was negatively related to time after the rainfall event $\left(R^{2}=0.84, P=0.03\right)$.

When leaf samples were exposed to rain events at hourly intervals, the release pattern did not change appreciably compared with a single rain event. A typical experiment is shown in Figure 2. Over all three experiments, 46, 35, 10, 5, 3, and $1 \%$ of the total ascospores were captured following the first to sixth rain events, respectively. The number of ascospores released was negatively related to the number of the rainfall event $\left(R^{2}=0.82, P=0.01\right)$.

Successive wetting and drying. When leaves were wetted to release the ascospores and then dried and rewetted on days 1, 3, 5,

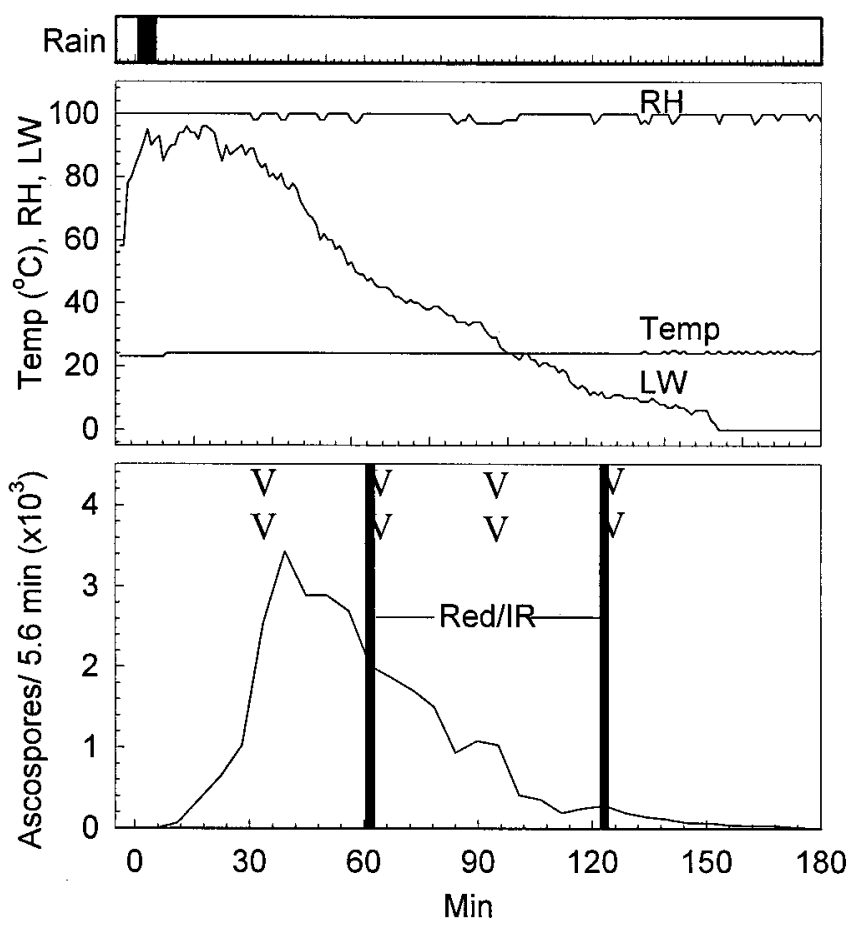

Fig. 6. Release of ascospores from pseudothecia of Mycosphaerella citri in response to a single rain event and two exposures to red/infrared or to momentary vibrations $(\mathrm{V})$ in a computer-controlled environmental chamber, under the relative humidity $(\mathrm{RH})$, leaf wetness (LW), and temperature (Temp) described.

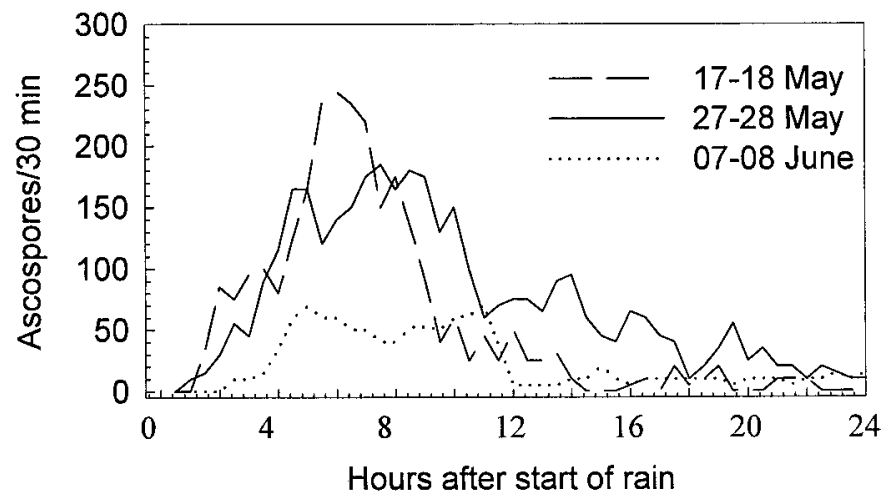

Fig. 7. Pattern of ascospore release following rain events on three dates in 2002, as determined by a Burkard volumetric spore sampler located in a grove of mixed citrus near Lake Alfred, FL. and 7, the majority of ascospores were released on the first day with successively fewer released after repeated wettings (Fig. 3). Averaged across the two experiments, 60, 18, 14, and $8 \%$ were recovered on days $1,3,5$, and 7 . The numbers released were negatively correlated with the day of exposure to a rain event $\left(R^{2}=\right.$ $0.91, P=0.04)$. In one of the three experiments, substantial numbers were observed on day 5 , indicating that more pseudothecia had matured.

Relative humidity. Low numbers of ascospores were released from leaves with pseudothecia exposed to 95 to $100 \% \mathrm{RH}$ for 360 min (Fig. 4). Low numbers were released early in the exposure period with a peak at about 200 to $220 \mathrm{~min}$. The number of ascospores released was positively related to the time of exposure to high humidity $\left(R^{2}=0.81, P=0.01\right)$ if the first hour of the experiment was omitted.

$R / I R$ irradiation and vibration. Irradiation with $\mathrm{R} / \mathrm{IR}$ did not have obvious effects on the pattern of spore release. When applied during and after the initial rain event, a small spike did occur in the middle of the period (Fig. 5), but that was not observed in a second experiment. The slope of the regression line for ascospore release with time in Figure 5 was significantly different from that in Figure 1 when the two were compared by the $t$ test $(t=3.6, P \leq$
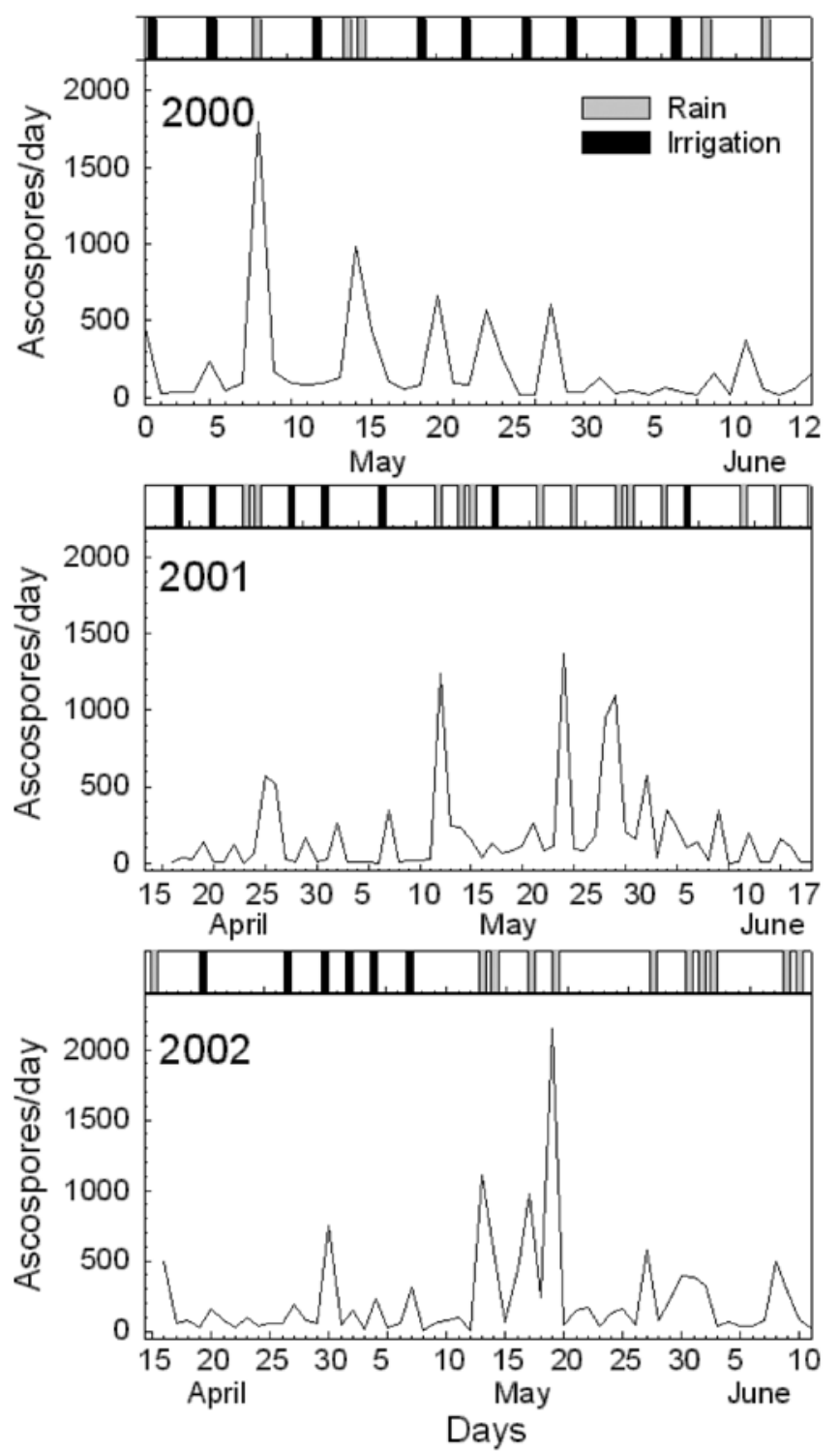

Fig. 8. Relationship of rainfall and irrigation events to ascospore release of Mycosphaerella citri, as determined by a Burkard volumetric spore sampler located in a grove of mixed citrus near Lake Alfred, FL. 
0.01). The IR irradiation may have slightly delayed the release of ascospores (Fig. 5). When leaves were exposed an hour or two after the rain event, no obvious change occurred in the course of ascospore release (Fig. 6). When the slope of the regression line for ascospore release was compared with that for data in Figure 1, there was no significant difference $(t=1.25, P \geq 0.05)$.

In two experiments, vibrations were applied to simulate wind movement of leaves. In no case was there any apparent deviation in the pattern of ascospore release due to vibration (Fig. 6).

Field studies. Rainfall and irrigation effects. Ascospore release was detected 1 to $2 \mathrm{~h}$ after a rain began in the three events that were followed (Fig. 7). Total release was less by 7 to 8 June because many of the spores had already been released. Peak release occurred 6 to $8 \mathrm{~h}$ after the rain began and continued for 12 to $16 \mathrm{~h}$. No differences were noted in the ascospore release pattern during daytime and nighttime hours (data not shown).

Wetting of the leaf litter on the floor of the grove by rainfall or microsprinkler irrigation induced release of ascospores (Fig. 8). Only low numbers of ascospores were released on days with no irrigation or rainfall. The average number of ascospores released was substantially higher on days with rain than on days with irrigation in all 3 years (Table 1). Ten percent or fewer of ascospores were released on days with no rain or irrigation.

Ascospore dispersal. The total precipitation during the three trapping periods investigated for vertical distribution ranged from 3.4 to $9.1 \mathrm{~mm}$, and wind speed varied from 1.6 to $2.3 \mathrm{~m} \mathrm{~s}^{-1}$. Low numbers of ascospores were captured at $7.5 \mathrm{~m}$, the greatest height tested. Ascospore capture was strongly negatively related to trapping height on all three sample days (Fig. 9A) and best fit a negative logarithmic pattern.

During the four 1-week periods when horizontal distribution was studied, the precipitation ranged from 0.9 to $54.5 \mathrm{~mm}$ per week and wind speeds averaged 1.3 to $3.4 \mathrm{~m} \mathrm{~s}^{-1}$. Wind direction was $187 \pm 67^{\circ}$ for the line of spore traps that were aligned straight west of the grove. The number of ascospore captured was greatest from 13 to 20 May when the number of mature pseudothecia was the highest. The number of ascospores captured declined linearly with distance from the grove, and the slopes were negative $(-0.0033$ to -0.0062$)$ in all 4 weeks, and all were significantly different from $0(P \leq 0.05)$.

\section{DISCUSSION}

Exposure of leaf litter bearing mature pseudothecia of $M$. citri to free moisture triggered release of high numbers of ascospores. Many ascomycotina, including $V$. inaequalis $(9,12)$, V. pirina (10), Anisograma anomala (20), Guignardia citricarpa (15), M. fijiensis (4), and Apiosporina morbosa (14), behave similarly. Initial ascospore release by $M$. citri occurred about 30 min after a simulated rain event in laboratory studies and was detectable after $2 \mathrm{~h}$ in the field in our studies. This difference probably represents the time required for pseudothecia and asci to be fully hydrated under field conditions, to swell and force asci through the ostiole where ascospores are forcibly ejected (1). Hydration under field conditions is probably not as uniform as in the CCEC because it is de- pendent on the amount of rain, canopy density, and depth of the leaf litter. Detection of ascospores in the field may also reflect the time required for sufficient spore release to occur to provide populations large enough for detection.

In our studies, a single rain event was sufficient to stimulate release of all of the ascospores from mature pseudothecia. Additional rain events did not trigger further release, such as that observed with $V$. inaequalis (7). High $\mathrm{RH}$ alone was sufficient to trigger release of low numbers of ascospores of $M$. citri in the CCEC as occurs with $V$. inaequalis $(9,16)$. Ascospores were detectable in the field even on days with no rain or irrigation, suggesting that dew triggers ascospore release under grove conditions. There was no indication that vibration increased ascospore release. R/IR radiation increases release of ascospores of $V$. inaequalis $(3,12)$ and $V$. pirina (10), and there is a strong diurnal effect on ascospore release with these species. There were only minor effects of vibration and irradiation using the CCEC, and there was no indication of diurnal effects in ascospore recovery in the field.
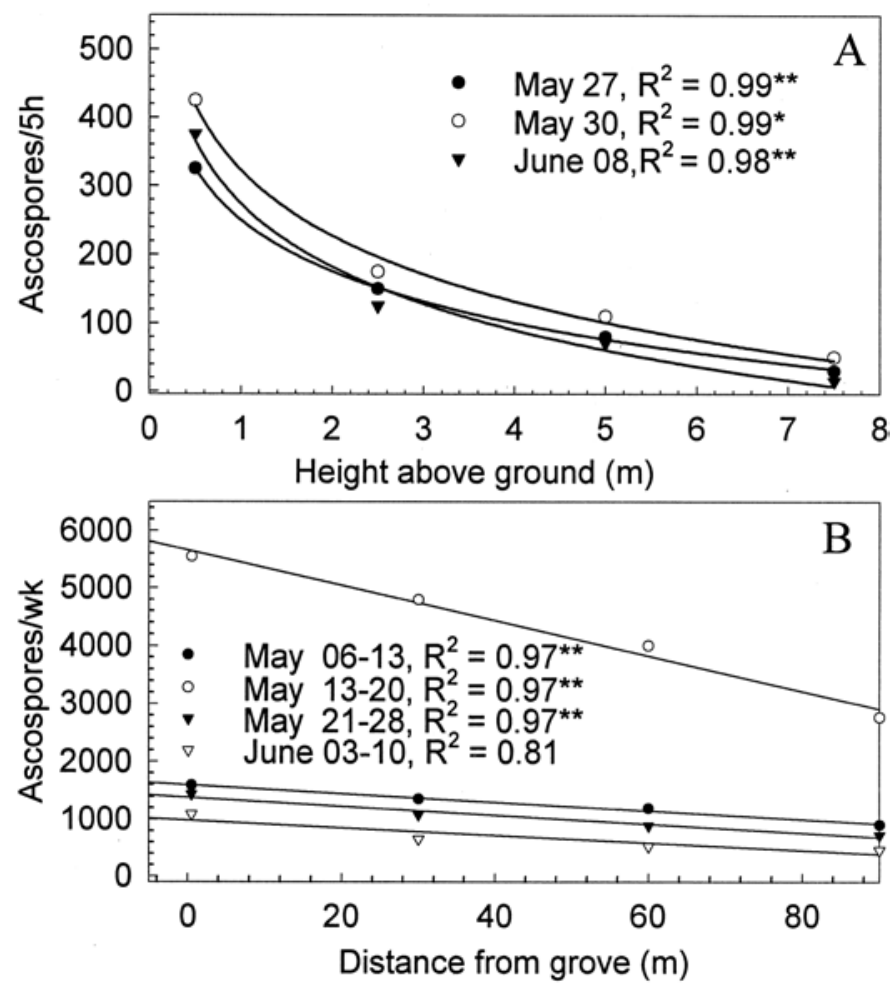

Fig. 9. A, Relationship between number of ascospores captured per liquidimpinger sampler and height above ground. Equations for the best fit lines were May $27-y=250.2-108.7 \ln x$; May $30-y=322.4-137.6 \ln x$; and June $8-y=273.6-132.4 \ln x$. B, Relationship between total ascospores captured per week by a Burkard volumetric spore sampler located in a grove of mixed citrus near Lake Alfred, FL, and horizontal distance for four 1 -week periods in 2002. In both cases, ascospore counts were square-root transformed prior to regression analysis. ${ }^{* *}=$ significant at $P \leq 0.01 ; *=$ significant at $P \leq 0.10$.

TABLE 1. Release of ascospores of Mycosphaerella citri from a grove of mixed fruit in Lake Alfred, FL, on days with rain, irrigation, or no water during peak release periods in 2000,2001 , and 2002

\begin{tabular}{|c|c|c|c|c|c|c|c|c|c|}
\hline \multirow[b]{2}{*}{ Class } & \multicolumn{3}{|c|}{2000} & \multicolumn{3}{|c|}{2001} & \multicolumn{3}{|c|}{2002} \\
\hline & No. of days & $\begin{array}{l}\text { Total precip. } \\
\quad(\mathrm{mm})\end{array}$ & Ascospores ${ }^{\mathrm{a}}$ & No. of days & $\begin{array}{l}\text { Total precip. } \\
\qquad(\mathrm{mm})\end{array}$ & Ascospores & No. of days & $\begin{array}{l}\text { Total precip. } \\
\qquad(\mathrm{mm})\end{array}$ & Ascospores \\
\hline Rain & 7 & 48 & $750 \pm 295(66)$ & 14 & 46 & $556 \pm 115(68)$ & 11 & 139 & $705 \pm 164(66)$ \\
\hline No water ${ }^{b}$ & 24 & 0 & $63 \pm 9(5)$ & 42 & 0 & $55 \pm 10(7)$ & 39 & 0 & $57 \pm 6(6)$ \\
\hline
\end{tabular}

${ }^{a}$ Ascospore captured per day \pm SE of the mean in a continuously operating Burkard volumetric spore trap (Burkard Scientific Sales, Ltd., Rickmansworth,

Hertfordshire, UK). Numbers in parentheses are the percentage of the total ascospores captured.

${ }^{\mathrm{b}}$ Days with no rain or irrigation. 
Rain stimulated release of more ascospores of $M$. citri than irrigation. This was probably attributable to the fact that irrigation wets only a portion of the surface area and thus of the leaf litter, whereas sufficient rainfall wets all of the litter. Irrigation was continued for about $3 \mathrm{~h}$ in most cases and was sufficient to thoroughly wet leaf litter as were most rainfall events. By irrigating during dry periods, it may be possible to induce ascospore release during periods unfavorable for infection and reduce disease. Ascospores of $M$. citri are fragile and short-lived and would likely die prior to infection under unfavorable conditions (28). However, epiphytic growth seems to be produced in abundance from the few ascospores produced in the summer rainy season (3). Because considerable infection can occur from relatively few ascospores (17), treatments and cultural manipulations designed to reduce inoculum or cause inoculum to be released when infection is not possible $(19,27)$ may not be highly effective for this disease.

The life cycles of many ascomycotina appear adapted to the phenology of the host plant. Ascospore production of $V$. inaequalis and Anisograma anomala peaks when the host is in the most susceptible stage $(6,9,13,20)$. In the case of Monilinia vacciniicorymbosi on blueberries, apothecium development of the pathogen has adapted to the phenology of individual cultivars of the host (11). Thus, with these temperate crops, pathogens tend to have life cycles closely adapted to the phenology of the host. However, we saw no evidence of this with $M$. citri. First, leaves of citrus appear to be susceptible even after they are mature (22), and conditions are favorable for infection and disease development during most of the year. The majority of the citrus leaves fall in February-March in Florida and decompose and produce pseudothecia over the next 2 to 3 months $(18,23,25)$. Ascospore production peaks in April and May, but some ascospores are produced year round $(21,25)$. Thus, ascomycete pathogens of tropical and subtropical crops, such as banana (4) and citrus, tend to have overlapping cycles throughout the year (25).

Ascospores of $M$. citri are small and can be dispersed at least $80 \mathrm{~m}$ and probably much further, as are those of $V$. inaequalis $(2,13)$ and Anisograma anomala (20). They are subject to desiccation and are fragile (28). However, if winds are strong and RH high, they could be quickly dispersed and establish new infections at some distance. Because it appears that relatively few ascospores are necessary to establish infections (17), significant disease may result from the few ascospores reaching the leaf from considerable distance. Thus, plot size for any experiments designed to reduce inoculum production would need to be large. Nevertheless, the greater severity of greasy spot on leaves on the lower canopy suggests that most of the infections result from ascospores dispersed short distances from the grove floor.

$M$. citri behaves much in the same manner as many other ascomycetes in that thorough wetting of leaf litter stimulates release of mature ascospores that are dispersed long distances vertically and horizontally by wind. However, ascospore release by this pathogen is not responsive to light as are some other ascomycetes. The host is susceptible throughout the year and the phenology of the pathogen is not synchronized with that of the host.

\section{ACKNOWLEDGMENTS}

This research was supported by the Florida Agricultural Experiment Station and a grant from the Florida Citrus Production Research Advisory Council, projects 991-36P and 013-16P, and approved for publication as Journal Series No. R-09225. We thank L. Zhang, T. Riley, and E. Taylor for technical assistance.

\section{LITERATURE CITED}

1. Aylor, D. E., and Anagostakis, S. L. 1991. Active discharge distance of ascospores of Venturia inaequalis. Phytopathology 81:548-551.

2. Aylor, D. E., and Sutton, T. B. 1992. Release of Venturia inaequalis ascospores during unsteady rain: Relationship to spore transport and deposition. Phytopathology 82:532-540.

3. Brook, P. J. 1969. Stimulation of ascospore release in Venturia inaequalis by far red light. Nature 222:390-392.

4. Burt, P. J. A., Rosenberg, L. J., Rutter, J., Ramirez, F., and Gonzales, O. H. 1999. Forecasting the airborne spread of Mycosphaerella fijiensis, the cause of black sigatoka disease on banana: Estimation of numbers of perithecia and ascospores. Ann. Appl. Biol. 135:369-377.

5. Gadoury, D. M., and MacHardy, W. E. 1982. Preparation and interpretation of squash mounts of pseudothecia of Venturia inaequalis. Phytopathology 72:92-95.

6. Gadoury, D. M., MacHardy, W. E., and Hu, C. 1984. Effects of temperature during ascus formation and frequency of ascospores discharge on pseudothecial development of Venturia inaequalis. Plant Dis. 68:223-225.

7. Gottwald, T. R., Trocine, T. M., and Timmer, L.W. 1997. A computercontrolled environmental chamber for the study of aerial fungal spore release. Phytopathology 87:1078-1084.

8. Hidalgo, H., Sutton, T. B., and Arauz, F. 1997. Epidemiology and control of citrus greasy spot on Valencia orange in the humid tropics of Costa Rica. Plant Dis. 81:1015-1022.

9. Hirst, J. M., and Stedman, O. J. 1962. The epidemiology of apple scab (Venturia inaequalis): Observations on the liberation of ascospores. Ann. Appl. Biol. 50:525-550.

10. Latorre, B. A., Yañez, P., and Rauld, E. 1985. Factors affecting release of ascospores by the pear scab fungus (Venturia pirina). Plant Dis. 69:213216.

11. Lehman, J. S., and Oudemans, P. V. 1997. Phenology of apothecium production in populations of Monilinia vaccinii-corymbosi from earlyand late-maturing cultivars. Phytopathology 87:218-223.

12. MacHardy, W. E., and Gadoury, D. M. 1986. Patterns of ascospore discharge by Venturia inaequalis. Phytopathology 76:985-990.

13. MacHardy, W. E., Gadoury, D. M., and Gessler, C. 2001. Parasitic and biological fitness of Venturia inaequalis: Relationship to disease management strategies. Plant Dis. 85:1036-1051.

14. McFadden-Smith, W., Northover, J., and Sears, W. 2000. Dynamics of ascospores release by Apiosporina morbosa from sour cherry black knots. Plant Dis. 84:45-48.

15. McOnie, K. C. 1964. Orchard development and discharge of ascospores of Guignardia citricarpa and the onset of infection in relation to the control of citrus black spot. Phytopathology 54:1448-1453.

16. Miller, P. M., and Waggoner, P. E. 1958. Dissemination of Venturia inaequalis ascospores. Phytopathology 48:416-419.

17. Mondal, S. N., and Timmer, L. W. 2002. The relationship of epiphytic growth of Mycosphaerella citri to greasy spot development on citrus and to disease control with fenbuconazole. Plant Dis. 86:186-192.

18. Mondal, S. N., and Timmer, L. W. 2002. Environmental factors affecting pseudothecial development and ascospore production of Mycosphaerella citri, the cause of citrus greasy spot. Phytopathology 92:1267-1275.

19. Mondal, S. N., and Timmer, L. W. 2003. The effect of urea, $\mathrm{CaCO}_{3}$, and dolomite on pseudothecial development and ascospore production of Mycosphaerella citri. Plant Dis. 87:478-483.

20. Pinkerton, J. N., Johnson, K. B., Aylor, D. E., and Stone, J. K. 2001. Spatial and temporal increase of eastern filbert blight in European hazelnut orchards in the Pacific Northwest. Phytopathology 91:1214-1223.

21. Russo, L. W., and Bistline, F. W. 1992. Results from thirteen year studyto-study effective spray timing with greasy spot (Mycosphaerella citri) spore population on east coast and ridge area groves. Proc. Fla. State Hortic. Soc. 105:19-20.

22. Timmer, L. W., and Gottwald, T. R. 2000. Greasy spot and similar diseases. Pages 25-28 in: Compendium of Citrus Diseases. L. W. Timmer, S. M. Garnsey, and J. H. Graham, eds. The American Phytopathological Society, St. Paul, MN.

23. Timmer, L. W., Gottwald, T. R., McGovern, R. J., and Zitko, S. E. 1995. Time of ascospore release and infection by Mycosphaerella citri in central and southwest Florida. Proc. Fla. State Hortic. Soc. 108:374-377.

24. Timmer, L. W., Reeve, R. J., and Davis, R. M. 1980. Epidemiology and control of citrus greasy spot on grapefruit in Texas. Phytopathology 70:863-867.

25. Timmer, L. W., Roberts, P. D., Darhower, H. M., Bushong, P. M., Stover, E. W., Peever, T. L., and Íbañez, A. M. 2000. Epidemiology and control of citrus greasy spot in different citrus-growing areas in Florida. Plant Dis. 84:1294-1298.

26. Whiteside, J. O. 1970. Etiology and epidemiology of citrus greasy spot. Phytopathology 60:1409-1414.

27. Whiteside, J. O. 1970. Effect of fungicides applied to citrus trees on perithecial development by the greasy spot fungus in detached leaves. Plant Dis. Rep. 54:865-869.

28. Whiteside, J. O. 1974. Environmental factors affecting infection of citrus leaves by Mycosphaerella citri. Phytopathology 64:115-120. 